\title{
28 Research Square \\ Effects Of Different Host-Plant Components On Physiological Indices In Spodoptera Frugiperda
}

\section{Min Fang}

Anhui Agricultural University

\section{Si-Han Lu}

Anhui Agricultural University

\section{Ling Yao}

Anhui Agricultural University

\section{Gui-ting Li}

Anhui Agricultural University

Ren-Wen Zheng

Anhui Agricultural University

Qing-Feng Tang ( $\square$ tangqf55@163.com )

Anhui Agricultural University

\section{Research Article}

Keywords: Spodoptera frugiperda, host-plant, correlation analysis, biological characteristics, relevance

Posted Date: March 7th, 2022

DOI: https://doi.org/10.21203/rs.3.rs-1398600/v1

License: () (i) This work is licensed under a Creative Commons Attribution 4.0 International License. Read Full License 


\section{Abstract}

Spodoptera frugiperda (J.E.Smith) (Lepidoptera: Noctuidae) is an invasive pest that ravaging crops in many provinces of China. In order to specifically control this invasive pest, understanding of the relationship between the insect and the hosts is necessary. In this study, we have compared the biological and nutritional indices of $S$. frugiperda by feeding it with five different host-plants (Zea mays, Triticum aestivum, Digitaria sanguinalis, Glycine max and Eleusine indica) under laboratory conditions. The biological and nutritional indices of $Z$. mays feeding $S$. frugiperda were the best. However, the pupa weight and fecundity of $S$. frugiperda fed with $G$. max and $E$. indica were significantly lower than those fed with other hosts, efficiency of conversion of digested food (ECD) and efficiency of conversion of ingested food (ECl) were also lower than others. The total phenol content of hosts was negatively correlated with the growth and nutrient accumulation of $S$. frugiperda, while the $\mathrm{C} / \mathrm{N}$ content was positively correlated. When fed on different host plants, the biological and nutritional indices of $S$. frugiperda were different, but all of them could complete the life cycle. Therefore, $S$. frugiperda also has a tendency to feed on other hosts, especially plants with high $\mathrm{C} / \mathrm{N}$ content, when $Z$. mays is insufficient.

\section{Introduction}

The fall armyworm (FAW), Spodoptera frugiperda (J.E.Smith) (Lepidoptera: Noctuidae), is one of the most important pests that has appeared in Asian countries. In the 1980s, researchers discovered two S. frugiperda populations associated with corn or rice, respectively ${ }^{1}$. Corn strains prefer corn, sorghum and cotton, while rice strains prefer rice and wild grasses instead ${ }^{2,3}$. Spodoptera frugiperda was first discovered on Chinese corn in January 2019. Over time, the $S$. frugiperda had spread to many provinces, threatening crop yields of China ${ }^{4,5}$. The damage caused by this insect is extensive. Although there is a big difference in crop-planting structure between north and south in China, it can still cause great loss and harm (even no grain harvest) due to the wide range of food sources in larval stage and strong migratory ability in adult stage $\mathrm{e}^{6,7,8}$. In addition crop hosts, some weeds such as Veronica polita, Euphorbiah elioscopial, E. indica, D. sanguinalis are also used as hosts by $S$. frugiperda9,10,11. Therefore, there are potential risks to the next crop due to the ability of noctuid transferring to other hosts around corn when the preferred or primary host (corn) is not abundant ${ }^{12}$.

Under suitable environmental conditions, the growth and development rate, reproduction rate and survival rate of insects are related to the types and quantity of the absorbed nutrients. Balanced and abundant nutrients are conducive to the growth, development and reproduction of insects ${ }^{13,14}$. Carbohydrate, amino acids, and protein was reported as important roles in the growth and development of phytophagous insects. Carbohydrate can provide the energy needed by insects growth and development ${ }^{15}$. The amino acid and protein of the host plants have a main effect on the larval feeding preference and larval growth, while sugars were only slightly stimulatory ${ }^{16,17}$. Besides these plants also contain secondary metabolites. It is known that secondary metabolites (phenols and flavonoids) found in plants can be considered as a defensive mechanism against insect pests ${ }^{18,19}$. The treatment of compounds in host plants after feeding can reflect the adaptability of insects to these hosts. However, the research on $S$. frugiperda mainly focuses on prevention and control ${ }^{20}$, or genomic and genetic differences studies ${ }^{21,22,23}$. In China, research about the characteristics of $S$. frugiperda on different hosts are reported rarely, let alone effects studies between the physical and chemical properties of host and the characteristics of $S$. frugiperda. The shortage of studies in this area seriously limits the determination of damage 
scope caused by $S$. frugiperda. At the same time, it also limits the prediction of host species that provide the source of insect accumulation.

In this study, five hosts associated with the corn ecology were carefully selected based on weed growth in cornfields and the crops grown around them in most areas of China. We assessed the growth development and the nutrient accumulation of immature stages on various host plants and the subsequent adult performance. We have determined the composition of different host plants using the detection method in the national standard. Insect herbivores and their host-plants correlation analysis were also investigated.

\section{Materials And Methods}

\subsection{Insects and Plant Material}

Spodoptera frugiperda was collected from Sunji cornfield in Huagang Town, Feixi County, Hefei City, Anhui Province in June 2019. Insects used in experiments had been fed on a regular artificial diet for more than ten generations. Larval were reared under controlled conditions of $25^{\circ} \mathrm{C} \pm 1{ }^{\circ} \mathrm{C}, 70 \% \pm 5 \%$ relative humidity $(\mathrm{RH})$, and a photoperiod of $16 \mathrm{~h}: 8 \mathrm{~h}(\mathrm{~L}: \mathrm{D})$. Egg masses laid by females were collected and deposited in box $(21 \mathrm{~cm}$ in length, $15 \mathrm{~cm}$ in width and $8 \mathrm{~cm}$ in height). Then the newly hatched larvae from the egg masses were collected for the experimental use.

Zea mays, Triticum aestivum, Glycine max, Digitaria sanguinalis and Eleusine indica were all planted in the agricultural extraction garden of Anhui Agricultural University in Hefei, Anhui Province, China. Leaves were cut from the plants and used throughout the experiments.

\subsection{Effects of different host plants on the biological characteristics of Spodoptera frugiperda}

We chose 120 newly hatched larval were reared with each host plant (Same weight) and they were divided into three equal groups in a selected sealed plastic box (21 cm in length, $15 \mathrm{~cm}$ in width and $8 \mathrm{~cm}$ in height), whose lids had been punctured with insects needles while bottom padded with filter paper. At the third instar, the larval were reared separately with 12-well plates $(2.25 \mathrm{~cm}$ in diameter, $4 \mathrm{~cm}$ in height). In the larval stage, fresh hosts (same weight) were replaced regularly every day and feces were cleaned up in time, meanwhile, the development period and the survival rate of the larval were recorded. Fifteen pupa were randomly selected to weigh their pupae on the second day after pupation. After eclosion, the duration and survival rate of all the pupa were recorded. Fifteen selected pairs of adults of $S$. frugiperda were reared in a cage (length $\times$ width $\times$ height $=70 \mathrm{~cm} \times 70 \mathrm{~cm} \times$ $70 \mathrm{~cm}$ ) and fed on $10 \%(\mathrm{w} / \mathrm{v})$ honey-water mixture. Eggs were collected every day to calculate the accurate egg numbers. The environmental controlled conditions of $25 \pm 1{ }^{\circ} \mathrm{C}, 70 \pm 5 \%$ relative humidity $(\mathrm{RH})$, and a photoperiod of $16: 8$ h (Light: Dark).

\subsection{Determination of nutritional indices of Spodoptera frugiperda feeding on different host plants}

Nutritional indicators were determinated according to the methods decribed previously ${ }^{24,25}$ with modifications. Some newly moulted 5th-instar larvae were selected to obtain average wet weight. The remaining food was replaced by fresh hosts and collected carefully every day, then it was dried to constant weight at $85^{\circ} \mathrm{C}$. The 
excrement was also collected and dried with the same procedure. At the end of 6th-instar (feeding and defecation were stopped), the average dry weight and wet weight were also measured.The dry-wet ratio of each feed and the dry-fresh ratio of larvae after feeding were calculated to obtain the dry pre-feeding weight of food and larvae.

$$
\begin{gathered}
\text { Relative Growth Rate (RGR) = G / }(\mathrm{B} \times \mathrm{T}) \\
\text { Relative Consumption Rate }(\mathrm{RCR})=\mathrm{I} /(\mathrm{B} \times \mathrm{T}) \\
\text { Approximate Digestibility (AD) }=(\mathrm{I}-\mathrm{F}) / \mathrm{I} \times 100 \% \\
\text { Efficiency of Conversion of Digested food }(\mathrm{ECD})=\mathrm{G} /(\mathrm{I}-\mathrm{F}) \times 100 \% \\
\text { Efficiency of Conversion of Ingested food }(\mathrm{ECI})=\mathrm{G} / \mathrm{I} \times 100 \%
\end{gathered}
$$

$\mathrm{T}$ (day) is the duration from newly moulted 5th-instar larval to the end of 6th-instar larval. $\mathrm{G}(\mathrm{g})$ is the increased dry weight of larval during T. I (g) is the dry weight of food consumed during T. F (g) is the dry weight of the excreta during T. B $(\mathrm{g})$ is the mean weight of larval during $\mathrm{T}$.

The environmental conditions are the same as above.

\subsection{Determination of nutrients and secondary substances in different host plants}

Soluble sugar: $100 \mathrm{mg}$ grated host tissue was added to $10 \mathrm{~mL}$ ethanol in a volumetric flask, then the volumetric flask was placed in $80^{\circ} \mathrm{C} \sim 85^{\circ} \mathrm{C}$ water bath with stirring for $30 \mathrm{~min}$. Afterwards, the solution was cooled down and centrifuged for 10 minutes at $5000 \mathrm{r} / \mathrm{min}$. Then the supernatant was transferred to a beaker. The beaker was placed in $85{ }^{\circ} \mathrm{C}$ water bath to evaporate the remanent ethanol, and then it was adjusted to $50 \mathrm{~mL}$ with distilled water. Ultimately, the content of soluble sugar in the extract was determined by anthrone colorimetry.

Protein: $2 \mathrm{~g}$ sample, $0.4 \mathrm{~g}$ copper sulfate, $6 \mathrm{~g}$ potassium sulphate, and $20 \mathrm{~mL}$ sulphuric acid were added into a dry $500 \mathrm{~mL}$ Kjeldahl flasks in turn. After shaking gently, the Kjeldahl flasks was slanted at 45-degree angle on asbestos net with a small funnel placed at mouth of the bottle. Then the bottle was carefully heated. When the content was completely carbonized (no foam was produced), the heat should be further increased to keep the liquid boiling slightly until the liquid changed to be clear blue-green. After another continuous heating for $0.5 \mathrm{~h} \sim 1$ $h$, the Kjeldahl flasks was removed out and cooled to room temperature. Then the solution was transferred to a $100 \mathrm{~mL}$ volumetric flask, meanwhile, a small amount of distilled water was used to wash the Kjeldahl flasks several times with the lotion transferred into the $100 \mathrm{~mL}$ volumetric flask, too. Finally, distilled water was added to the scale line and the solution was mixed thoroughly. The protein content was determined by Automatic Kjeldahl nitrogen analyzer.

Total amino acids: $2 \mathrm{~mL}$ hydrochloric acid $(6 \mathrm{~mol} / \mathrm{L})$ was added into homogenate $(2 \mathrm{~g})$ and the well mixed solution was added to $10 \mathrm{~mL}$ by hydrochloric acid in a hydrolysate tube. 3 drops phenol were added into the solution and the hydrolysate tube was put into refrigerant for $3 \sim 5$ minutes. The tube was then connected with the suction pipe of a vacuum pump for vacuumizing, afterwards, it was filled in with nitrogen (repeating for 3 times) for sealing. The sealed hydrolytic bottle was put into an electric blast incubator at $110{ }^{\circ} \mathrm{C} \pm 1{ }^{\circ} \mathrm{C}$ for $22 \mathrm{~h}$ and it was taken out and cooled to room temperature after heating. The mixed solution was filtered and the filtrate was transferred into a $50 \mathrm{~mL}$ volumetric flask to bring to volume by distilled water. $1 \mathrm{~mL}$ liquid from the volumetric flask was dried and steamed in a $15 \mathrm{~mL}$ test tube, and then it was dissolved by $2 \mathrm{~mL}$ sodium citrate 
buffer solution. After being passed through a $0.22 \mu \mathrm{m}$ filter membrane, the solution was transferred to an amino acid automatic analyzer (JJG1046-2011) injection bottle for accurate determination.

$\mathrm{C} / \mathrm{N}$ ratio: $0.1 \mathrm{~g}$ host sample, $0.1 \mathrm{~g}$ silver sulfate powder, $5 \mathrm{~mL}$ potassium dichromate standard solution (0.8 $\mathrm{mol} / \mathrm{L}$ ) and $5 \mathrm{~mL}$ concentrated sulfuric acid were added into a test tube. The $\mathrm{C} / \mathrm{N}$ ratio results were obtained through digestion and titration procedures. Each samples were repeated for 3 times.

Water: $10 \mathrm{~g}$ leaves of each host were weighed and dried in a drying box at $85{ }^{\circ} \mathrm{C}$. After drying, the mass of the corresponding dried leaves was weighed by an electronic balance to calculate the water content of the leaves. Repeat this process for 3 times.

Total flavonoids: $1 \mathrm{~g}$ sample and $30 \mathrm{~mL}$ anhydrous ethanol were added into a $100 \mathrm{~mL}$ conical flask for extraction in an ultrasonic cleaner $(1 \mathrm{~h})$. After cooling to room temperature, the solution was filtered to a $50 \mathrm{~mL}$ volumetric flask and bought to volume by anhydrous ethanol. Sample absorbance at $420 \mathrm{~nm}$ was measured, and the obtained standard curve was used to calculate the total flavonoid contents.

Tannin: $2 \mathrm{~g}$ homogenized sample and $80 \mathrm{~mL}$ distilled water were added into a $100 \mathrm{~mL}$ volumetric flask in boiling water to extract tannin for 30 minutes. After being cooled to room temperature, brought it to marked volume by distilled water. $2 \mathrm{~mL}$ solution was sucked into a centrifuge tube for centrifugation at $8000 \mathrm{r} / \mathrm{min}$ (4 minutes). 1 $\mathrm{mL}$ supernatant (after centrifugation), $5 \mathrm{~mL}$ water, $1 \mathrm{~mL}$ mixture solution of sodium tungstate and sodium molybdate, and $3 \mathrm{~mL}$ sodium carbonate were mixed for color reaction ( 2 hours). After this step, sample absorbance was measured at $765 \mathrm{~nm}$ and the obtained standard curve was used to calculate the tannin content.

Total phenol: $0.5 \mathrm{~g}$ sample was milled to slurry with $3 \mathrm{~mL} 95 \%$ ethanol and filtered, then the filtrate was transferred to a $25 \mathrm{~mL}$ volumetric flask and brought to volume by $95 \%$ ethanol. $2 \mathrm{~mL}$ sample solution and $2 \mathrm{~mL}$ folin were mixed and shaked for 3 minutes in $10 \mathrm{~mL}$ test tube, then $2 \mathrm{~mL} 10 \%$ sodium carbonate was added. After vibrating and standing ( 1 hour), the mixed solution was measured by colourimetric absorbance at $700 \mathrm{~nm}$ and the total phenol content was calculated from the standard curve.

All the above samples were fresh host leaves.

\subsection{Data analysis}

Excel 2003 was used to conduct statistics on the original data. SPSS 23.0 was used to analyze the contents of different host components, nutritional indices and biological indices of $S$. frugiperda feeding on different host plants by one-way analysis of variance (one-way ANOVA) and the results were tested by Tukey's HSD $(P<0.05)$. The relationship between chemical components of different hosts and growth and nutritional indicators of $S$. frugiperda was also analyzed by SPSS 23.0 with pearson correlation coefficient.

\section{Results}

\subsection{Biological characteristics of Spodoptera frugiperda feeding on different host plants}

As shown in Table 1, the survival rates of early-instars larval (larva of instar 1 to 3 ) and older-instar larval (larva of instar 4 to 6 ) of S. frugiperda (99.17\% and $81.52 \%$, respectively) fed on Z. mays are much higher than larval fed 
on other hosts, while larval fed on G. max have the lowest survival rate (85.83\% and 64.06\%). The developmental durations of older-instar larval fed on E. indica (10.43 days) is the longest, while early-instars larval fed on $Z$. mays have the shortest developmental durations (6.22 days).

Table 1

Survival rates, developmental durations, pupa weight and fecundity of Spodoptera frugiperda on Zea mays, Triticum aestivum, Glycine max, Digitaria sanguinalis and Eleusine indica.

\begin{tabular}{|c|c|c|c|c|c|}
\hline Indicators & $\begin{array}{l}\text { Zea mays } \\
\text { (mean } \pm \\
\text { SE) }\end{array}$ & $\begin{array}{l}\text { Triticum } \\
\text { aestivum } \\
\text { (mean } \pm \\
\text { SE) }\end{array}$ & $\begin{array}{l}\text { Digitaria } \\
\text { sanguinalis } \\
\text { (mean } \pm \text { SE) }\end{array}$ & $\begin{array}{l}\text { Glycine } \\
\text { max } \\
\text { (mean } \pm \\
\text { SE) }\end{array}$ & $\begin{array}{l}\text { Eleusine } \\
\text { indica } \\
\text { (mean } \pm \\
\text { SE) }\end{array}$ \\
\hline $\begin{array}{l}\text { Survival rate of early-instars } \\
\text { larval } / \%\end{array}$ & $\begin{array}{l}99.17 \pm \\
0.83 a\end{array}$ & $\begin{array}{l}93.33 \pm \\
0.83 b\end{array}$ & $\begin{array}{l}92.50 \pm 1.44 \\
b\end{array}$ & $\begin{array}{l}85.83 \pm \\
0.83 \mathrm{c}\end{array}$ & $\begin{array}{l}93.33 \pm \\
0.83 b\end{array}$ \\
\hline $\begin{array}{l}\text { Survival rate of older-instar larval } \\
/ \%\end{array}$ & $\begin{array}{l}81.52 \pm \\
0.77 a\end{array}$ & $\begin{array}{l}77.69 \pm \\
0.69 \mathrm{~b}\end{array}$ & $\begin{array}{l}73.88 \pm 0.59 \\
c\end{array}$ & $\begin{array}{l}64.06 \pm \\
1.19 \mathrm{~d}\end{array}$ & $\begin{array}{l}72.31 \pm \\
1.04 \mathrm{c}\end{array}$ \\
\hline $\begin{array}{l}\text { Development period of early- } \\
\text { instars larval /days }\end{array}$ & $\begin{array}{l}6.22 \pm \\
0.44 d\end{array}$ & $\begin{array}{l}6.29 \pm 0.01 \\
d\end{array}$ & $6.53 \pm 0.05 c$ & $\begin{array}{l}6.68 \pm 0.06 \\
b\end{array}$ & $\begin{array}{l}6.84 \pm 0.05 \\
a\end{array}$ \\
\hline $\begin{array}{l}\text { Development period of older- } \\
\text { instar larval /days }\end{array}$ & $\begin{array}{l}9.20 \pm \\
0.17 \mathrm{c}\end{array}$ & $\begin{array}{l}9.62 \pm 0.05 \\
\text { bc }\end{array}$ & $9.80 \pm 0.03 b$ & $\begin{array}{l}10.40 \pm \\
0.12 \mathrm{a}\end{array}$ & $\begin{array}{l}10.43 \pm \\
0.16 \mathrm{a}\end{array}$ \\
\hline Pupa weight /mg & $\begin{array}{l}296.67 \pm \\
2.96 \mathrm{a}\end{array}$ & $\begin{array}{l}285.33 \pm \\
3.18 b\end{array}$ & $\begin{array}{l}273.33 \pm 1.20 \\
c\end{array}$ & $\begin{array}{l}257.00 \pm \\
5.03 \mathrm{~d}\end{array}$ & $\begin{array}{l}259.67 \pm \\
4.10 \mathrm{~d}\end{array}$ \\
\hline Fecundity /eggs & $\begin{array}{l}1308.00 \pm \\
6.35 \mathrm{a}\end{array}$ & $\begin{array}{l}1204.67 \pm \\
9.24 \mathrm{~b}\end{array}$ & $\begin{array}{l}1119.33 \pm \\
8.99 \mathrm{c}\end{array}$ & $\begin{array}{l}1059.33 \pm \\
26.97 \mathrm{~d}\end{array}$ & $\begin{array}{l}994.00 \pm \\
19.40 \mathrm{~d}\end{array}$ \\
\hline \multicolumn{6}{|c|}{ low - instar larval : larva of instar 1 to 3 ; } \\
\hline \multicolumn{6}{|c|}{ older - instar larval : larva of instar 4 to 6.} \\
\hline \multicolumn{6}{|l|}{ Fecundity : egg-production amount. } \\
\hline
\end{tabular}

Table 1 shows that the pupal weight of $S$. frugiperda fed on Z.mays in larval stage is heaviest, up to $296.67 \mathrm{mg}$, followed by larval fed on T. aestivum $(285.33 \mathrm{mg}$ ). larval fed on G. max has the lowest pupal weight (257 mg). Egg-production amount (representation of fecundity) of $S$. frugiperda fed on Z.mays in the larval stage has the largest number, as much as 1308 eggs, while the minimum number (994 eggs) of S. frugiperda fed on E. indica in larval stage.

Based on these results, it can be concluded that biological characteristics of $S$. frugiperda fed on different host plants in larval stage had significant difference.

\subsection{Nutritional indices of Spodoptera frugiperda feeding on different host plants}

The nutritional indices in Table 2 reveals that the RGR $(12.80 \mathrm{mg} / \mathrm{mg} / \mathrm{d}), \mathrm{ECD}(13.43 \%)$, and ECl (6.82\%) of $S$. frugiperda larval fed on $Z$. mays are much higher than larval fed on other hosts. The RCR $(2.44 \mathrm{mg} / \mathrm{mg} / \mathrm{d}) \mathrm{of} S$. 
frugiperda larval fed on E. indica were significantly higher than larval fed on other hosts. As shown in Table 2, the $A D$ of $S$. frugiperda fed on different host plants in larval stage had no significant difference.

Table 2

The nutritional indices determination of Spodoptera frugiperda on Zea mays, Triticum aestivum, Glycine max, Digitaria sanguinalis and Eleusine indica.

\begin{tabular}{|c|c|c|c|c|c|}
\hline Indicators & $\begin{array}{l}\text { Zea mays } \\
\text { (mean } \pm \text { SE) }\end{array}$ & $\begin{array}{l}\text { Triticum } \\
\text { aestivum } \\
\text { (mean } \pm \text { SE) }\end{array}$ & $\begin{array}{l}\text { Digitaria } \\
\text { sanguinalis } \\
\text { (mean } \pm \text { SE) }\end{array}$ & $\begin{array}{l}\text { Glycine max } \\
\text { (mean } \pm \text { SE) }\end{array}$ & $\begin{array}{l}\text { Eleusine } \\
\text { indica } \\
\text { (mean } \pm \text { SE) }\end{array}$ \\
\hline $\begin{array}{l}\mathrm{RGR} \\
/ \mathrm{mg} / \mathrm{mg} / \mathrm{d}\end{array}$ & $\begin{array}{l}12.80 \pm 0.19 \\
a\end{array}$ & $11.16 \pm 0.28 b$ & $10.38 \pm 0.02 b c$ & $9.96 \pm 0.24 c$ & $10.95 \pm 0.34 b$ \\
\hline $\begin{array}{l}\mathrm{RCR} \\
/ \mathrm{mg} / \mathrm{mg} / \mathrm{d}\end{array}$ & $1.88 \pm 0.01 c$ & $2.07 \pm 0.06 b c$ & $2.09 \pm 0.01 b c$ & $2.12 \pm 0.05 b$ & $2.44 \pm 0.08 a$ \\
\hline$A D / \%$ & $\begin{array}{l}50.78 \pm 0.31 \\
a\end{array}$ & $50.88 \pm 0.43 a$ & $51.00 \pm 0.34 a$ & $\begin{array}{l}50.02 \pm 0.25 \\
a\end{array}$ & $50.56 \pm 0.36 a$ \\
\hline $\mathrm{ECD} / \%$ & $\begin{array}{l}13.43 \pm 0.20 \\
a\end{array}$ & $10.63 \pm 0.58 b$ & $9.73 \pm 0.05 b c$ & $9.42 \pm 0.14 \mathrm{c}$ & $8.88 \pm 0.05 c$ \\
\hline $\mathrm{ECl} / \%$ & $6.82 \pm 0.06 a$ & $5.40 \pm 0.25 b$ & $4.96 \pm 0.01 c$ & $\begin{array}{l}4.71 \pm 0.06 \\
\text { cd }\end{array}$ & $4.49 \pm 0.05 d$ \\
\hline
\end{tabular}

RGR: Relative Growth Rate;

RCR: Relative Consumption Rate;

AD: Approximate Digestibility;

ECD: Efficiency of Conversion of Digested food;

ECl: Efficiency of Conversion of Ingested food.

The data in the table are "mean \pm SE ", different lowercase letters following data in the same row indicate significant difference $(P<0.05)$.

\subsection{Nutrient composition and secondary substance content of different host plants}

Figure 1 shows that there are some differences in the nutrient contents and the secondary substances among different host-plants (all $P$ values < 0.05). The soluble sugar (Fig. 1A), protein (Fig. 1B), total amino acids (Fig. 1C), total phenol (Fig. 1D) contents of Z.mays are lowest, while those of G. max are highest. The total flavonoid (Fig. 1E), tannin (Fig. 1F) contents of E. indica are lowest, while those of G. max are highest. As shown in Fig. 1G, the $\mathrm{C} / \mathrm{N}$ content is higher in Z. mays than other hosts, while it is much lower in D. sanguinalis. However, the water contents for all hosts display no significant differences (Fig. 1H).

\subsection{Correlation analysis between host plant and Spodoptera frugiperda}

As shown in Table 3, the survival rate of early-instars larval and older-instar larval are mainly affected by the protein $(\mathrm{R}=-0.862$ and $\mathrm{R}=-0.793)$ (all $P$ values $<0.01)$, total amino acids $(\mathrm{R}=-0.773$ and $\mathrm{R}=-0.651)($ all $P$ 
values $<0.01)$, total phenols $(\mathrm{R}=-0.943$ and $\mathrm{R}=-0.916)$ (all $P$ values $<0.01)$, otal flavonoids $(\mathrm{R}=-0.706$ and $\mathrm{R}$ $=-0.643)$ (all $P$ values $<0.01), \mathrm{C} / \mathrm{N}(\mathrm{R}=0.516$ and $\mathrm{R}=0.605)$ (all $P$ values $<0.05$ ), and water $(\mathrm{R}=0.801$ and $\mathrm{R}=$ 0.847 ) (all $P$ values $<0.01$ ) in the host plants. In addition, soluble sugar content has a significant effect on the survival rate of early-instars larval $(R=-0.634, P<0.05)$ but the survival rate of older-instar larval is not affected by it obviously. The developmental period of larval (early-instars and older-instar) is negatively correlated with $\mathrm{C} / \mathrm{N}(\mathrm{R}=-0.795$ and $\mathrm{R}=-0.701)$ (all $P$ values $<0.01$ ) but positively correlated with total phenol content $(\mathrm{R}=0.560$ and $\mathrm{R}=0.707)(P<0.05$ and $P<0.01$, respectively). Pupa weight is negatively correlated with protein $(\mathrm{R}=-0.531$, $P<0.05)$, total amino acid $(R=-0.605, P<0.05)$ and total phenol $(R=-0.758, P<0.01)$; and it is positively correlated with $\mathrm{C} / \mathrm{N}(\mathrm{R}=0.776, P<0.01)$. The fecundity is mainly negatively correlated with the total amino acid content $(\mathrm{R}=-570, P<0.05)$ of the host, and positively correlated with $\mathrm{C} / \mathrm{N}(\mathrm{R}=0.887, P<0.01)$.

Table 3

Correlation between analysis from the phytochemical content of different hosts and biological indicators of Spodoptera frugiperda after feeding on different hosts using pearson correlation coefficient.

\begin{tabular}{|c|c|c|c|c|c|c|c|c|}
\hline Indicators & $\begin{array}{l}\text { Soluble } \\
\text { sugar }\end{array}$ & Protein & $\begin{array}{l}\text { Total } \\
\text { amino } \\
\text { acids }\end{array}$ & $\begin{array}{l}\text { Total } \\
\text { phenols }\end{array}$ & $\begin{array}{l}\text { Total } \\
\text { flavonoids }\end{array}$ & Tannin & $\mathrm{C} / \mathrm{N}$ & Water \\
\hline $\begin{array}{l}\text { Survival rate } \\
\text { of early- } \\
\text { instars larval } \\
/ \%\end{array}$ & $-0.634^{\star}$ & $-0.862^{\star \star}$ & $-0.773 * \star$ & $-0.943^{\star *}$ & $-0.706 * \star$ & -0.440 & $0.516 *$ & $0.801^{* *}$ \\
\hline $\begin{array}{l}\text { Survival rate } \\
\text { of older- } \\
\text { instar larval } \\
/ \%\end{array}$ & -0.457 & $-0.793^{\star \star}$ & $-0.651 * \star$ & $-0.916 * \star$ & $-0.643^{\star *}$ & -0.217 & $0.605^{\star}$ & $0.847^{\star \star}$ \\
\hline $\begin{array}{l}\text { Development } \\
\text { period of } \\
\text { early-instars } \\
\text { larval / days }\end{array}$ & -0.023 & 0.289 & 0.438 & 0.560 * & 0.190 & -0.350 & $-0.795^{\star \star}$ & -0.413 \\
\hline $\begin{array}{l}\text { Development } \\
\text { period of } \\
\text { older-instar } \\
\text { larval /days }\end{array}$ & -0.272 & $0.522^{\star}$ & $0.559 *$ & $0.707 * \star$ & 0.281 & -0.165 & $-0.701^{\star \star}$ & $-0.578 *$ \\
\hline $\begin{array}{l}\text { Pupa weight } \\
\text { /mg }\end{array}$ & -0.235 & $-0.531 *$ & $-0.605^{\star}$ & $-0.758 * \star$ & -0.400 & 0.080 & $0.776^{\star *}$ & 0.589 \\
\hline $\begin{array}{l}\text { Fecundity } \\
\text { /eggs }\end{array}$ & -0.003 & -0.217 & $-0.570 *$ & -0.531 & -0.149 & 0.318 & 0.887 ** & 0.230 \\
\hline \multicolumn{9}{|c|}{ low - instar larval : larva of instar 1 to 3 ; } \\
\hline \multicolumn{9}{|c|}{ older - instar larval : larva of instar 4 to 6.} \\
\hline \multicolumn{9}{|c|}{ Fecundity : egg-production amount. } \\
\hline The data in th & able are & relation & ficient, " $*$ & . ᄃ & 0 & & t $P<0.01^{\prime \prime}$ & \\
\hline
\end{tabular}

According to the data in Table 4, the RGR of $S$. frugiperda has remarkably positive correlation with water $(R=$ $0.545, P<0.01)$ and $\mathrm{C} / \mathrm{N}(\mathrm{R}=0.746, P<0.01)$. The $\mathrm{RGR}$ also has significant negative correlation with protein $(\mathrm{R}=$ - 0.671, $P<0.01)$, total amino acids $(\mathrm{R}=-0.887, P<0.01)$, total phenols $(\mathrm{R}=-0.889, P<0.01)$ and total 
flavonoids $(\mathrm{R}=-0.716, P<0.01)$. The $\mathrm{RCR}$ is prominently positively correlated with $\mathrm{C} / \mathrm{N}(\mathrm{R}=0.707, P<0.01)$ and $A D$ is positively correlated with water content $(R=0.558, P<0.05)$. ECD and $E C I$ are significantly positively correlated with $\mathrm{C} / \mathrm{N}(\mathrm{R}=0.875$ and $\mathrm{R}=0.874$, respectively) (all $P$ values $<0.01)$, but negatively correlated with total amino acids $(\mathrm{R}=-0.801$ and $\mathrm{R}=-0.805$, respectively) (all $P$ values $<0.01)$ and total phenols $(\mathrm{R}=-0.728$ and $\mathrm{R}=$ - 0.749, respectively) (all $P$ values $<0.01$ ).

Table 4

Correlation between analysis from the phytochemical content of different hosts and nutrition indicators of Spodoptera frugiperda after feeding on different hosts using pearson correlation coefficient.

\begin{tabular}{|c|c|c|c|c|c|c|c|c|}
\hline Indicators & $\begin{array}{l}\text { Soluble } \\
\text { sugar }\end{array}$ & Protein & $\begin{array}{l}\text { Total } \\
\text { amino } \\
\text { acids }\end{array}$ & $\begin{array}{l}\text { Total } \\
\text { phenols }\end{array}$ & $\begin{array}{l}\text { Total } \\
\text { flavonoids }\end{array}$ & Tannin & $\mathrm{C} / \mathrm{N}$ & Water \\
\hline $\begin{array}{l}\text { RGR } \\
/ \mathrm{mg} / \mathrm{mg} / \mathrm{d}\end{array}$ & -0.445 & $-0.671^{\star \star}$ & $-0.887^{\star *}$ & $-0.889^{* *}$ & $-0.716^{* *}$ & -0.407 & $0.746^{\star \star}$ & $0.545^{\star \star}$ \\
\hline $\begin{array}{l}\mathrm{RCR} \\
/ \mathrm{mg} / \mathrm{mg} / \mathrm{d}\end{array}$ & -0.021 & 0.062 & -0.375 & 0.259 & -0.146 & -0.483 & $-0.707^{\star \star}$ & 0.055 \\
\hline$A D / \%$ & -0.277 & -0.428 & -0.117 & -0.373 & -0.159 & 0.007 & 0.057 & $0.558^{*}$ \\
\hline $\mathrm{ECD} / \%$ & -0.279 & -0.435 & $-0.801^{\star \star}$ & $-0.728^{\star \star}$ & -0.394 & -0.026 & $0.875^{\star *}$ & 0.345 \\
\hline $\mathrm{ECl} / \%$ & -0.298 & -0.480 & $-0.805^{\star *}$ & $-0.749^{\star *}$ & -0.403 & -0.021 & $0.874^{\star \star}$ & 0.380 \\
\hline \multicolumn{9}{|c|}{ RGR: Relative Growth Rate; } \\
\hline \multicolumn{9}{|c|}{ RCR: Relative Consumption Rate; } \\
\hline \multicolumn{9}{|c|}{ AD: Approximate Digestibility; } \\
\hline \multicolumn{9}{|c|}{ ECD: Efficiency of Conversion of Digested food; } \\
\hline \multicolumn{9}{|c|}{ ECl: Efficiency of Conversion of Ingested food. } \\
\hline The data in & e table ar & orrelation & efficient, “” & gnificant a & $P<0.05, * *=$ & nificant a & $P<0.01^{\prime \prime}$ & \\
\hline
\end{tabular}

\section{Discussion}

As the polyphagous insects, Spodoptera frugiperda will produce different host plants adaptability when feeding on different hosts ${ }^{12,26,27}$. For the most species of insects, developmental stage of larval, pupa weight, and number of eggs laid by female can be used to judge the best host plants for insects as a criteria ${ }^{28,29}$. In this study, after fed on $Z$. mays, survival rate and fecundity of $S$. frugiperda are highest, and the development period were the shortest. Followed by fed on T. aestivum, however, the survival rate of the early-instars larval and older-instar larval of $S$. frugiperda were lowest when fed on G. max. In addition, the development period of the older-instar larval fed on G. max and E. indica were relatively longer, and the pupal weight and fecundity were lower than fed on other hosts. Some studies have shown that when insects fed on poor-quality hosts, they have to eat more hosts to remove the effect of the changes in host ${ }^{24}$. In the present study, S. frugiperda has a higher RGR on $E$. indica, but the $\mathrm{ECl}$ is lower relatively. In contrast, Spodoptera frugiperda fed on Z. mays has the lowest RCR and the highest ECl. Thus, combining the effects of fed on five hosts in this study on the growth and development of S. frugiperda, Z. mays were optimal host and E. indica is the least suitable host for S. frugiperda. 
There are different nutrient and secondary substance content with different hosts ${ }^{20}$. In general, the insects fed on high-quality hosts have shorter duration of development, lower consumption rate, higher growth rate, and higher food processing efficiency ${ }^{13,31,32}$. According to the correlation analysis of the host phytochemical content with the biological and nutritional indices of $S$. frugiperda, we find that $\mathrm{C} / \mathrm{N}$ plays an active role in the growth of $S$. frugiperda. This is consistent with the conclusion obtained by Holopainen ${ }^{33}$. Phenolic substances, one of the main chemical defense substances in the host plants ${ }^{13,34}$, have a significant negative correlation to the growth and development and nutritional indices of $S$. frugiperda. Besides, the total flavonoid content affects the survival rate of the early-instars and older-instar larval and RGR of $S$. frugiperda. There is no significant correlation between the tannin content and the entire growth and development of $S$. frugiperda. In other related studies, it has been found that the protein and amino acid content of plants can promote the growth and development of insects ${ }^{35}$, but the results obtained in this study are contrary to the results. This might be caused by other factors in the feeding process. There is a complex dynamic relationship between the content of phytochemicals and the herbivorous insects ${ }^{34}$. The nutrient content and secondary metabolite content of the host plant will change the feeding behavior and feeding response of insects. Therefore, it is impossible to make a broad generalization of the effect of a single host phytochemical on herbivorous insects, and the quality of the host plant is also affected by the physical properties (hardness, surface hair density and shape), which need to be further studied.

In this study, although the adaptability to D. sanguinalis, G. max and E. indica is not as good as that to Z. mays and $T$. aestivum, $S$. frugiperda can still complete its life cycle after feeding. Therefore, it is necessary to pay attention not only to crops, but also to the species and quantity of the surrounding weeds in the control process of $S$. frugiperda. Besides, it is found in this study that the higher $\mathrm{C} / \mathrm{N}$ content, the more favorable effect for $S$. frugiperda. It has also been reported that the level of fertilization will affect the $\mathrm{C} / \mathrm{N}$ expression in plants in other related literatures ${ }^{36,37}$. Therefore, the control of $S$. frugiperda can also be carried out by adjusting the amount of fertilizer.

\section{Statement}

The guidelines for experimental and field studies on plants (either cultivated or wild), including the collection of plant material, comply with relevant institutional, national and international guidelines and legislation.

\section{Declarations}

\section{Data availability statement}

Some or all data that support the findings of this study are available from the corresponding author upon reasonable request.

\section{Acknowledgments}

This research was supported by the Major Special Science and Technology Project of Anhui Province, China (Grant No. 201903a06020027), Key Program of Anhui Province Tobacco Corporation, China (Grant No. 20170551024), and Key Project for Academic and Technical Leader Candidate of Anhui Province, China (Grant No. 2019H238).

\section{Author Contribution}

Page $10 / 13$ 
Conceptualization, Q.T.; Data curation, M.F., S.L. and Q.T.; Formal analysis, M.F., L.Y., R.Z., J.H., and Q.T.; Funding acquisition, Q.T.; Investigation, Q.T.; Methodology, S.L., R.Z., J.H. and Q.T.; Project administration, Q.T.; Resources, Q.T.; Supervision, Q.T.; Validation, J.H. and Q.T.; Writing - original draft, M.F. and S.L.; Writing - review \& editing, J.H., G.L. and Q.T.

\section{Disclosure}

The authors declare they have no conflict interests.

\section{References}

1. Pashley, D. P. Host-associated genetic differentiation in fall armyworm (Lepidoptera: Noctuidae): a sibling speciescomplex? Ann. Entomol. Soc. Am. 79, 898-904 (1986).

2. Hay-Roe, M. M., Reagher, R. L. \& Nagoshi, R. N. Effects of cyanogenic plants on fitness in two host strains of the fall armyworm (Spodoptera frugiperda). J. Chem. Ecol. 37, 1314-1322 (2011).

3. Nagoshi, R. N. et al. Comparative molecular analyses of invasive fall armyworm in togo reveal strong similarities to populations from the eastern United States and the Greater Antilles. Plos One. 12, e0181982 (2017).

4. Guo, J. F., Zhao, J. Z., He, K. L., Zhang, F. \& Wang, Z.Y. Potential invasion of the crop-devastating insect pest fall armyworm Spodoptera frugiperda to China. Plant. Protect. 44, 1-10 (2018a).

5. Zhang, L. <bi>et al</bi>. Molecular identification of invasive fall armyworm Spodoptera frugiperda in Yunnan province. Plant. Protect. 45, 19-24 (2019).

6. Sena, D. G., Pinto, F. A. C., Queriroz, D. M. \& Viana, P. A. Fall armyworm damaged maize plant identification using digital images. Biosyst. Eng. 85, 449-454 (2003).

7. Lima, M. S., Silva, P. S. L., Oliveira, O. F., Silva, K. M. B. \& Freitas, F. C. L. Maize yield response to weed and fall armyworm controls. Planta Daninha. 28, 103-111 (2010).

8. Jing, D. P. et al. Initial detections and spread of invasive Spodoptera frugiperda in China and comparisons with other noctuid larval in cornfields using molecular techniques. Insect. Sci. 00, 1-11 (2019).

9. Wang, W. W. et al. The population growth of Spodoptera frugiperda on six cash crop species and implications for its occurrence and damage potential in China. Insects. 11, 639 (2020).

10. Yao, L., Fang, M., Li, X. M., Li, G. T. \& Tang, Q. F. Oviposition and feeding selectivity of Spodoptera frugiperda to three weeds. Plant. Protect. 46, 181-184 (2020).

11. Fang, M., Yao, Y., Tang, Q.F., Li, G.T. \& Jiang, X.C. Adaptability of Spodoptera frugiperda to several weeds. Plant Protect. 47, 1055-1061 (2020).

12. Guo, J. F., Zhang, M. D., Gao, Z.P., Wang, D. J., He, K. L. \& Wang, Z. Y. Comparison of larval performance and oviposition preference of Spodoptera frugiperda among three host plants: potential risks to potato and tobacco crops. Insect. sci. https: //doi:10.1111/1744-7917-12830 (2020b).

13. Awmack, C. S. \& Leather, S. Host plant quality and fecundity in herbivorous insects. Annu. Rev. Entomol. 47, 817-844 (2002).

14. Nosil, P., Crespi, B. J. \& Sandoval, C. P. Host-plant adaptation drives the parallel evolution of reproductive isolation. Nature. 417, 440-443 (2002). 
15. Beenakkers, A. Carbohydrate and fat as a fuel for insect flight. A comparative study. J. Insect Physiol. 15, 353-361 (1969).

16. Hedin, P. A., Poe, W. E. \& Lindig, O.H. Amino acids in pecan weevil, southwestern corn borer and tarnished plant bug, and at their feeding sites. Comp. Biochem. Physiol. 68, 261-263 (1981a).

17. Hedin, P. A., Williams, W. P., Davis, F. M \& Buckley, P. M. Roles of amino acids, protein, and fiber in leaf-feeding resistance of corn to the fall armyworm. J. Chem. Ecol. 16:1977-1995 (1990b).

18. Abir, S., Yangui, I., Hamdi, S. H., Sahbani, Z., Jemaa, \& J. M. B. Secondary metabolites fluctuation caused by Liriomyza cicerina (Diptera: Agromyzidae) infestation in chickpea, faba bean and lentil crops. Int. J. of Trop. Insect Sc. https: //doi: 10.1007/s42690-021-00626-0 (2021).

19. Salminen, J. P. \& Lempa, K. Effects of hydrolysable tannins on a herbivorous insect: fate of individual tannins in insect digestive tract. Chemoecology. 12, 203-211 (2002).

20. Tambo, J. A. et al. Tackling fall armyworm (Spodoptera frugiperda) outbreak in Africa: an analysis of farmers' control actions. Int. J. Pest Manage. 1-13 (2019).

21. Nagoshi, R. N. \& Meagher, R. L. Using intron sequence comparisons in the triose-phosphate isomerase gene to study the divergence of the fall armyworm host strains. Insect. Mol. Biol. 25, 324-337 (2016).

22. Gouin, A. et al. Two genomes of highly polyphagous lepidopteran pests (Spodoptera frugiperda, Noctuidae) with different host-plant ranges. Sci. Rep-UK. 7, 11816 (2017).

23. Stuhl, C. J., Meagher, R. L. \& Nagoshi, R. N. Genetic variation in neonate behavior of fall armyworm (Lepidoptera: Noctuidae). Fla. Entomol. 91, 151-158 (2008).

24. Pinto, J. R. L. et al. Artificial corn-based diet for rearing Spodoptera frugiperda (Lepidoptera: Noctuidae). J. Insect. Sci. 19, 1-8 (2019).

25. Scriber, J. M. \& Slansky, F. J. The nutritional ecology of immature insects. Annu. Rev. Entomol. 26, 183-211 (1981).

26. Naseri, B., Fathipour, Y., Moharramipour, S. \& Hosseininaveh, V. Comparative life history and fecundity of Helicoverpa armigera (hubner) (lepidoptera: noctuidae) on different soybean varieties. Entomol. Sci. 12, 147-154 (2009).

27. Razmjou, J., Naseri, B. \& Hemati, S. A. Comparative performance of the cotton bollworm, Helicoverpa armigera (Hubner) (Lepidoptera: Noctuidae) on various host plants. J. Pest. Sci. 87, 29-37 (2014).

28. Greenberg, S. M., Sappington, T. W., Sétamou, M. \& Liu, T.X. Beet armyworm (Lepidoptera: Noctuidae) host plant preferences for oviposition. Environ. Entomol. 31, 142-148 (2002).

29. Xu, M., Pang, Y. H., Wang, H. T., Li, Q. L. \& Liu, T. X. Effects of four host plants on biology and food utilization of the cutworm, Spodoptera litura. J. Insect. Sci. 10, 1-14 (2010).

30. Wilson, J. K, Ruiz, L., Duarte, J. \& Davidowitz, G. The nutritional landscape of host plants for a specialist insect herbivore. Ecol. Evolution. 00,1-10 (2019).

31. Vellau, H., Sandre, S. L. \& Tammaru, T. Effect of host species on larval growth differs between instars: The case of a geometrid moth (Lepidoptera: Geometridae). Eu. J. Entomol. 110, 599-604 (2013).

32. Cunha, U. S. et al. Resistência de genótipos de milho para cultivo em várzeas subtropicais à lagarta-docartucho Spodoptera frugiperda. Ciênc. Rural. 38, 1125-1128 (2008).

33. Holopainen, J. K. The nutritional ecology of maturation in a carnivorous insect. Entomol. Exp. Appl. 104, 137-142 (2002). 
34. Steinbauer, M. J. Role of phytochemistry in insect nutrition. Austral Entomology. <backgroundcolor:\#FFCC66;bu>57</background-color:\#FFCC66;bu>, 214-219 (2018).

35. Dai, Q. X. et al. Effects of different corn varieties on development and reproduction of Spodoptera frugiperda. Cnki. J. Appl. Ecol. 31, 3273-3281 (2020).

36. Ibrahim, M. H., Jaafar, H. Z. E., Rahmat, A. \& Rahman, Z. A. Effects of nitrogen fertilization on synthesis of primary and secondary metabolites in three varieties of Kacip Fatimah (Labisia Pumila Blume). Int. J. Mol. Sci. 12, 5238-5254 (2011).

37. Deng, X. F. et al. Spatial and temporal trends of soil total nitrogen and $\mathrm{C} / \mathrm{N}$ ratio for croplands of East China. Geoderma. 361, 114035 (2020).

\section{Figures}
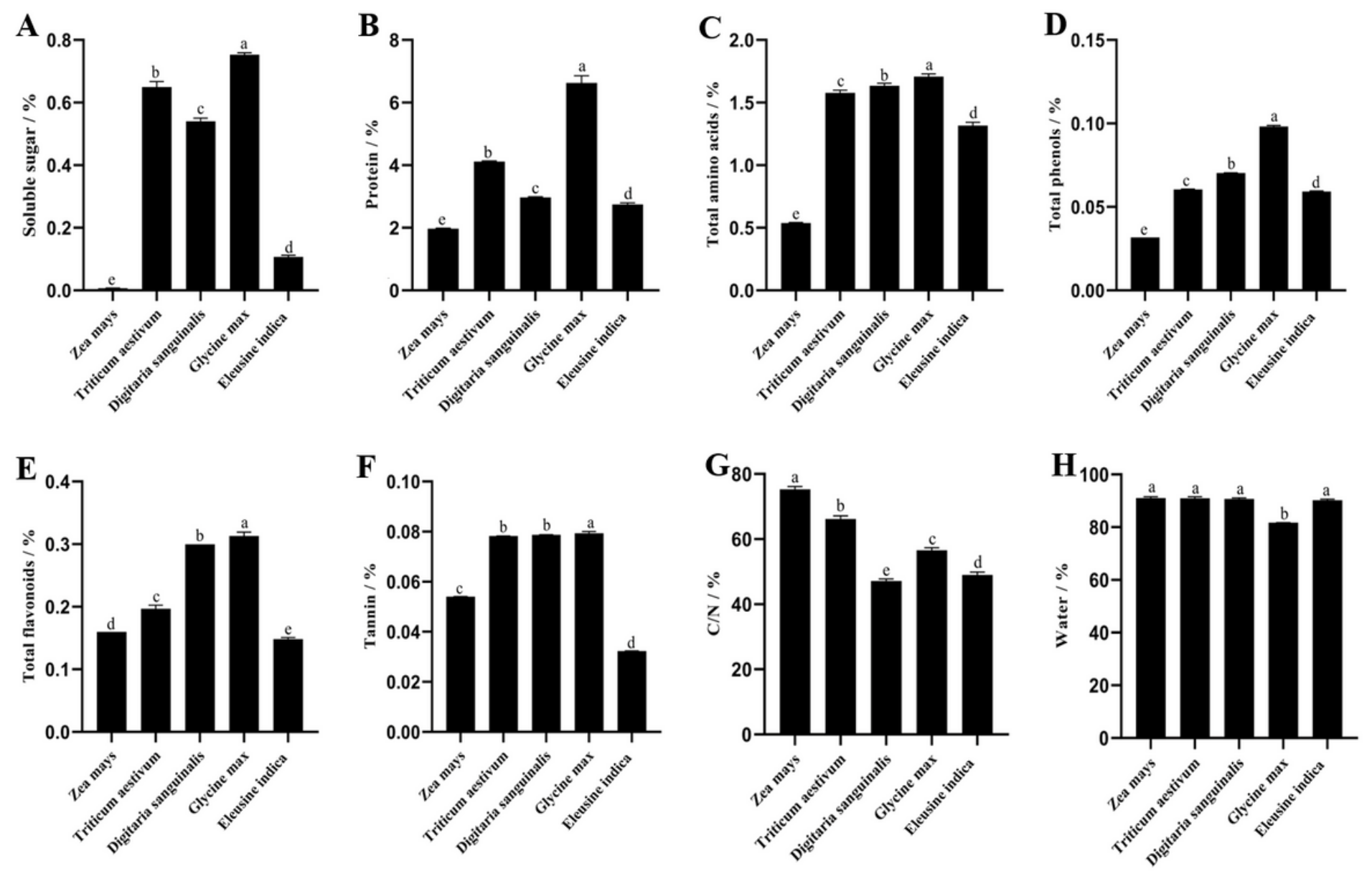

\section{Figure 1}

Mean \pm SE numbers of phytochemical content of different hosts (Zea mays, Triticum aestivum, Glycine max, Digitaria sanguinalis and Eleusine indica) (A) Soluble sugar (B) Protein (C) Total amino acids (D) Total phenols (E) Total flavonoids $(F)$ Tannin $(G) C / N(H)$ Water. Different lowercase letters indicate means are significantly different at $P<0.05$. 